\title{
Diagnostic and prognostic impact of cytokeratin 18 expression in human tumors: a tissue microarray study on 11,952 tumors
}

Anne Menz ${ }^{1}$, Timo Weitbrecht ${ }^{1}$, Natalia Gorbokon ${ }^{1}$, Franziska Büscheck' , Andreas M. Luebke ', Martina Kluth', Claudia Hube-Magg ${ }^{1}$, Andrea Hinsch' , Doris Höflmayer ${ }^{1}$, Sören Weidemann ${ }^{1}$, Christoph Fraune ${ }^{1}$,

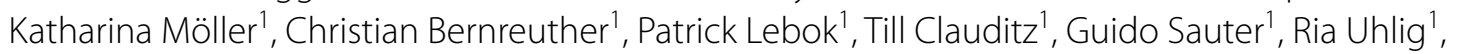
Waldemar Wilczak', Stefan Steurer ${ }^{1}$, Sarah Minner ${ }^{1}$, Eike Burandt ${ }^{1}$, Rainer Krech², David Dum ${ }^{1}$, Till Krech ${ }^{1,2}$, Andreas Marx ${ }^{1,3}$ and Ronald Simon ${ }^{1 *}$ (1)

\begin{abstract}
Background: Cytokeratin 18 (CK18) is an intermediate filament protein of the cytokeratin acidic type I group and is primarily expressed in single-layered or "simple" epithelial tissues and carcinomas of different origin.

Methods: To systematically determine CK18 expression in normal and cancerous tissues, 11,952 tumor samples from 115 different tumor types and subtypes (including carcinomas, mesenchymal and biphasic tumors) as well as 608 samples of 76 different normal tissue types were analyzed by immunohistochemistry in a tissue microarray format.

Results: CK18 was expressed in normal epithelial cells of most organs but absent in normal squamous epithelium. At least an occasional weak CK18 positivity was seen in 90 of 115 (78.3\%) tumor types. Wide-spread CK18 positivity was seen in 37 (31.9\%) of tumor entities, including adenocarcinomas of the lung, prostate, colon and pancreas as well as ovarian cancer. Tumor categories with variable CK18 immunostaining included cancer types arising from CK18 positive precursor cells but show CK18 downregulation in a fraction of cases, tumor types arising from CK18 negative precursor cells occasionally exhibiting CK18 neo-expression, tumors derived from normal tissues with variable CK18 expression, and tumors with a mixed differentiation. CK18 downregulation was for example seen in renal cell cancers and breast cancers, whereas CK18 neo-expression was found in squamous cell carcinomas of various origins. Down-regulation of CK18 in invasive breast carcinomas of no special type and clear cell renal cell carcinomas (cCRCC) was related to adverse tumor features in both tumors $(p \leq 0.0001)$ and poor patient prognosis in ccRCC $(p=0.0088)$. Up-regulation of CK18 in squamous cell carcinomas was linked to high grade and lymph node metastasis $(p<0.05)$. In summary, CK18 is consistently expressed in various epithelial cancers, especially adenocarcinomas.
\end{abstract}

Conclusions: Down-regulation or loss of CK18 expression in cancers arising from CK18 positive tissues as well as CK18 neo-expression in cancers originating from CK18 negative tissues is linked to cancer progression and may reflect tumor dedifferentiation.

Keywords: Cytokeratin 18 (CK18), Tissue microarray, Immunohistochemistry

*Correspondence: R.Simon@uke.de

${ }^{1}$ Institute of Pathology, University Medical Center Hamburg-Eppendorf, Martinistr. 52, 20246 Hamburg, Germany

Full list of author information is available at the end of the article

\section{Introduction}

Cytokeratin 18 (CK18) belongs to the cytokeratin acidic type I group (CK9-CK12) and is encoded by a gene located at chromosome 12q13 (Moll et al. 1982; Waseem original author(s) and the source, provide a link to the Creative Commons licence, and indicate if changes were made. The images or other third party material in this article are included in the article's Creative Commons licence, unless indicated otherwise in a credit line to the material. If material is not included in the article's Creative Commons licence and your intended use is not permitted by statutory regulation or exceeds the permitted use, you will need to obtain permission directly from the copyright holder. To view a copy of this licence, visit http://creativecommons.org/licenses/by/4.0/. 
et al. 1990). CK18 is an intermediate filament protein that forms heteropolymers with its co-expressed complementary type II keratin partner CK8, which assembles into keratin filaments-the major structural component in the cytoplasm of epithelial cells (Moll et al. 1982; Fuchs and Weber 1994). CK18 is primarily expressed in singlelayered or "simple" epithelial tissues of, for example, the liver, kidney, breast, prostate, gastrointestinal tract as well as in cancers arising from CK18 positive epithelial cells (Oshima et al. 1996; Cajaiba et al. 2006; Skinnider et al. 2005; Faridi et al. 2018). Beside the important structural function, CK18 was also shown to play a role in apoptosis (Caulin et al. (2000); Gilbert et al. 2001), cell cycle progression (Galarneau et al. 2007), and cancer-related signaling pathways. For example, CK18 hypoglycosylation is linked to decreased Akt1 kinase activity and reduced cell survival (Rotty et al. 2010). CK18 upregulation was described to be associated with decreased cell motility and invasiveness via the Wnt-pathway (Yee et al. 2010), and CK18 may be involved in the control of the ERK1/2MAPK pathway (Zhang et al. 2006; Gilbert et al. 2004).

In surgical pathology, CK18 is used as an epithelial marker to identify CK18 positive adenocarcinomas that arise from different CK18 positive normal epithelia (Oshima et al. 1996; Weng et al. 2012). CK18 expression was also suggested as a potential prognostic marker. For example, decreased CK18 expression was found to be related to tumor progression in breast and colorectal cancers (Woelfle et al. 2004; Knosel et al. 2006). Elevated CK18 protein levels were found to be associated with unfavorable tumor features in oral and esophageal squamous cell carcinomas (Makino et al. 2009; Fillies et al. 2006) as well as in non-small cell lung cancers (Zhang et al. 2016). CK18 antibodies have been used as diagnostic cancer markers for more than thirty years (Oshima et al. 1996). However, the literature on the prevalence of CK18 expression is controversial for many cancers (Walker et al. 2007; Shao et al. 2012; Bartek et al. 1991; Malzahn et al. 1998; Young et al. 2002; Lyda and Weiss 2000; Broers et al. 1988; Hsu et al. 2010; Ueda et al. 1993; Lam et al. 2001; Moll et al. 1993; Levy et al. 1992; Notohara et al. 2000; Akiba et al. 2016; Shimonishi et al. 2000; Yoshikawa et al. 1998; Sinard 1999; Poniecka and Alexis 1999; Balm et al. 1996; Nanda et al. 2012; Agaimy et al. 2012; Miettinen and Fetsch 2000; Raju 1988; Chen et al. 2011; Ishida et al. 2017; Nhung et al. 1999; Safadi et al. 2019). For example, CK18 positivity has been described in $30 \%$ to $100 \%$ of oral squamous cell carcinomas (Nanda et al. 2012; Safadi et al. 2019), $0 \%$ to $100 \%$ of non-small cell lung cancers (Chen et al. 2011; Nhung et al. 1999), and $0 \%$ to $43 \%$ of esophageal squamous cell carcinomas (Makino et al. 2009; Ishida et al. 2017). These conflicting data are likely to be caused by the use of different antibodies, immunostaining protocols, and criteria to determine CK18 positivity in these studies.

To better understand the prevalence and significance of CK18 expression in cancer, a comprehensive study analyzing a large number of neoplastic and non-neoplastic tissues under highly standardized conditions is needed. Therefore, CK18 expression was analyzed in more than 14,000 tumor tissue samples from 115 different tumor types and subtypes as well as 76 non-neoplastic tissue categories by immunohistochemistry (IHC) in a tissue microarray (TMA) format in this study.

\section{Materials and methods}

Tissue microarrays (TMAs)

Our normal tissue TMA was composed of 8 samples from 8 different donors for each of 76 different normal tissue types (608 samples on one slide). The cancer TMAs contained a total of 14,579 primary tumors from 115 tumor types and subtypes. Detailed histopathological data on grade, $\mathrm{pT}$ and $\mathrm{pN}$ status were available from 4191 cancers (breast, kidney, bladder, various kinds of squamous cell carcinoma). Clinical follow up data were available from 1178 breast cancer and 847 kidney cancer patients with a median follow-up time of $49 / 39$ months (range 1-88/1-250). The composition of both normal and cancer TMAs is described in detail in the results section. All samples were from the archives of the Institutes of Pathology, University Hospital of Hamburg, Germany, the Institute of Pathology, Clinical Center Osnabrueck, Germany, and Department of Pathology, Academic Hospital Fuerth, Germany. Tissues were fixed in $4 \%$ buffered formalin and then embedded in paraffin. The TMA manufacturing process was described earlier in detail (Dancau et al. 2016; Kononen et al. 1998). In brief, one tissue spot (diameter: $0.6 \mathrm{~mm}$ ) was transmitted from a cancer containing donor block ( $\geq 70 \%$ cancer cells) in an empty recipient paraffin block. The use of archived remnants of diagnostic tissues for manufacturing of TMAs and their analysis for research purposes as well as patient data analysis has been approved by local laws (HmbKHG, $\$ 12$ ) and by the local ethics committee (Ethics commission Hamburg, WF-049/09). All work has been carried out in compliance with the Helsinki Declaration.

\section{Immunohistochemistry}

Freshly cut TMA sections were immunostained on one day and in one experiment. Slides were deparaffinized and exposed to heat-induced antigen retrieval for $5 \mathrm{~min}$ in an autoclave at $121^{\circ} \mathrm{C}$ in $\mathrm{pH} 7.8$ buffer. Primary antibody specific for CK18 (mouse monoclonal, MSVA-118, MS Validated Antibodies, GmbH, Hamburg, Germany) was applied at $37{ }^{\circ} \mathrm{C}$ for $60 \mathrm{~min}$ at a dilution of 1:300. Bound antibody was then visualized using the EnVision 
Kit (Agilent, CA, USA) according to the manufacturer's directions. For tumor tissues, the percentage of positive neoplastic cells was estimated, and the staining intensity was semiquantitatively recorded $(0,1+, 2+, 3+)$. For statistical analyses, the staining results were categorized into four groups. Tumors without any staining were considered negative. Tumors with $1+$ staining intensity in $\leq 70 \%$ of cells and $2+$ intensity in $\leq 30 \%$ of cells were considered weakly positive. Tumors with $1+$ staining intensity in $>70 \%$ of cells, $2+$ intensity in $31-70 \%$, or $3+$ intensity in $\leq 30 \%$ were considered moderately positive. Tumors with $2+$ intensity in $>70 \%$ or $3+$ intensity in $>30 \%$ of cells werde considered strongly positive.

\section{Statistics}

Statistical calculations were performed with JMP 14 software (SAS Institute Inc., NC, USA). Contingency tables and the chi $^{2}$-test were performed to search for associations between CK18 and tumor phenotype. Survival curves were calculated according to Kaplan-Meier. The
Log-Rank test was applied to detect significant differences between groups.

\section{Results}

\section{Technical issues}

A total of $11,952(82.0 \%)$ of 14,579 tumor samples were interpretable in our TMA analysis. The remaining 2627 (18.0\%) samples were not analyzable due to the lack of unequivocal tumor cells or loss of the tissue spot during the technical procedures. On the normal tissue TMA, a sufficient number of samples was always interpretable per tissue to determine the CK18 expression.

\section{CK18 in normal tissues}

CK18 was highly expressed in epithelial cells of the stomach (except parietal cells), duodenum, ileum, appendix, colon, rectum (Fig. 1a), gall bladder, pancreas (weaker staining in Islet cells than in acinus cells; Fig. 1b), endometrium, endocervix, alveolar cells of the lung, cytotrophoblast and syncytiotrophoblast of the placenta,

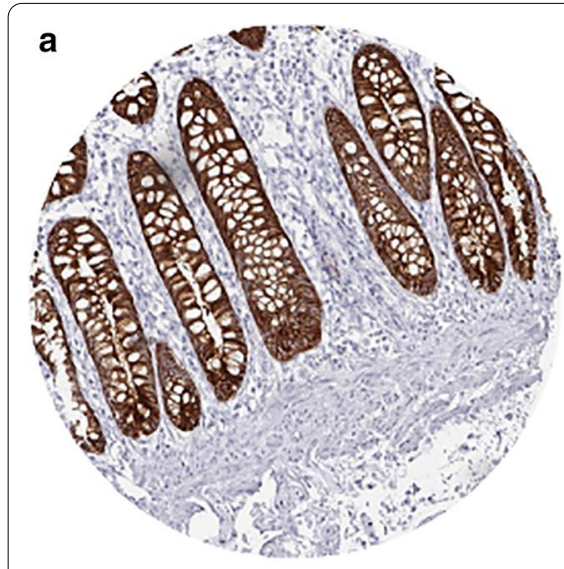

d

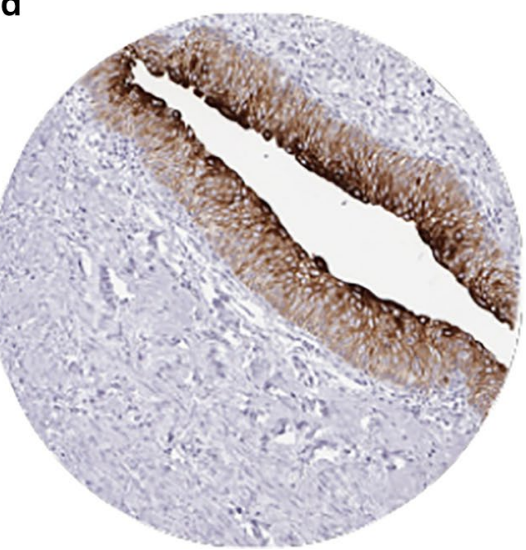

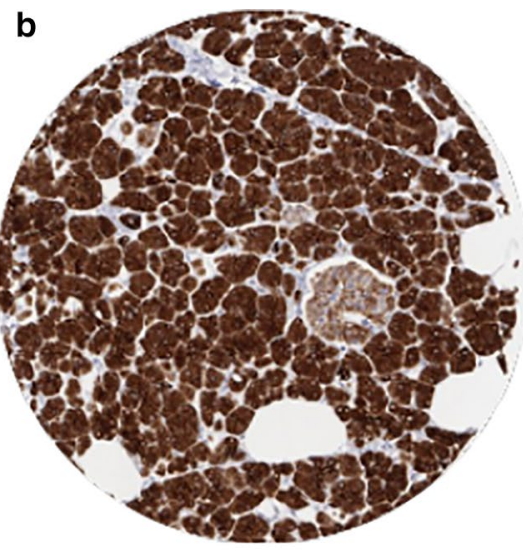

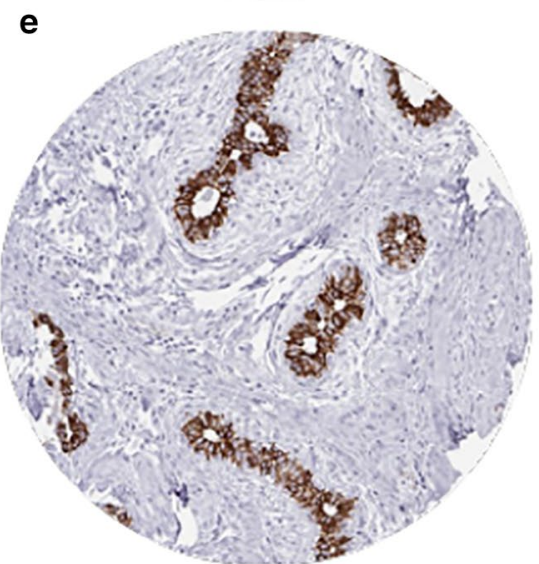

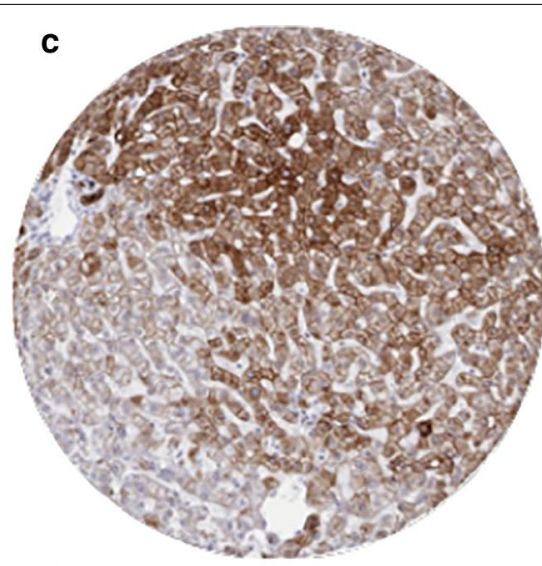

f

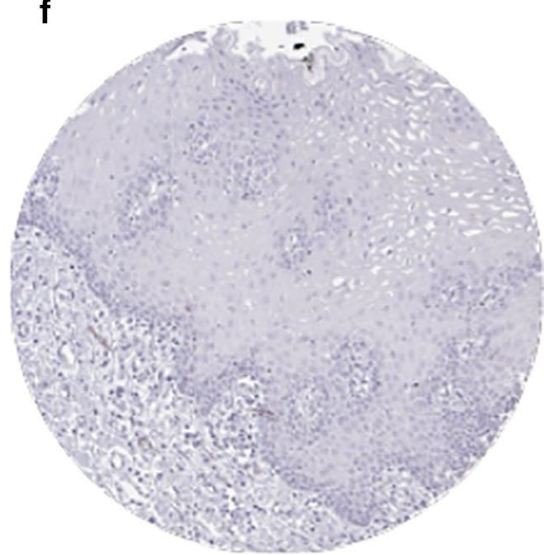

Fig. 1 Cytokeratin 18 (CK18) expression in normal tissues. The images show strong CK18 staining in epithelial cells from rectum (a) and pancreas (b), a zonal staining variability in the liver (c), strongly positive umbrella cells and a gradually decreasing staining intensity from superficial to basal urothelial cells in the bladder (d), strong positivity in acinus cells but absent staining in basal cells of the breast epithelium (e) and a complete lack of staining in squamous epithelium of the oral mucosa (f) 
and in all cells of the adenohypophysis (variable staining intensity). Liver tissue exhibited a zonal variability in hepatocyte staining ranging from negative to strongly positive (Fig. 1c). Bile ducts were always positive. Urothelium of the kidney and urinary bladder showed a strong staining in umbrella cells and a gradually decreasing staining intensity from superficial to basal urothelial cells (Fig. 1d). Salivary glands showed strong staining of serous and mucinous cells but somewhat weaker positivity in excretion ducts, especially in large ones. Some ducts only showed few positive cells or complete CK18 negativity. In the kidney, proximal and distal tubuli as well as collecting ducts were CK18 positive. In the ovary, follicular cells and follicular cysts stained positive as well as some cells of the corpus luteum. A strong positive staining of glandular cells with weaker and probably absent staining in basal cells was seen in prostate, respiratory mucosa of bronchus and paranasal sinuses, epididymis, seminal vesicle, and breast glands (Fig. 1e). In lymph nodes, tonsil, spleen, and thymus delicate fibrillar staining caused by CK18 positive fibroblastic reticulum occurred mainly in the interfollicular area. In the thymus, some cellular components of Hassal bodies were CK18 positive, and merkel cells in the skin and hair follicles were CK18 positive. CK18 was absent in all mesenchymal tissues, the stroma of the ovary, posterior lobe of the pituitary gland, brain, bone marrow, lymph nodes, spleen and lymphocytes in tonsil and thymus. Staining was also negative in all squamous epithelia from esophagus, skin, lip, oral cavity (Fig. 1f), tonsil, and anal canal, hair follicles, sebaceous glands, testis (except some weak staining in some Sertoli cells in 2 of 8 samples), adrenal gland (except some cells with weak staining in $1 / 8$ samples), aorta, heart, striated muscle, skeletal muscle, myometrium, muscular wall of the gastrointestinal tract, kidney pelvis, and the urinary bladder, corpus spongiosum of the penis, bone marrow.

\section{CK18 in neoplastic tissues}

Cytoplasmic immunostaining was observed in 9098 (76.1\%) of 11,952 analyzable tumors, including $45.0 \%$ with strong, $16.5 \%$ with moderate, and $14.6 \%$ with weak staining intensity. At least an occasional weak CK18 positivity was detected in 90 of 115 (78.3\%) different tumor types and tumor subtypes and 78 (67.8\%) tumor types and tumor subtypes had at least one tumor exhibiting strong positivity. Representative images of CK18 positive tumors are shown in Fig. 2. The highest frequencies of CK18 positivity were seen in adenocarcinomas of the lung, cervix uteri, small intestine, prostate, and pancreas, some breast cancer and thyroid cancer subtypes, and most of all neuroendocrine tumors and carcinomas.
A detailed description of the immunostaining results is given in Table 1 and Fig. 3.

\section{CK18 expression, tumor phenotype, and prognosis}

The relationship between CK18 expression and clinicopathological data could be analyzed in two cancer types derived from CK18 positive precursor cells (breast and kidney cancer), one cancer type derived from epithelium with variable CK18 expression (urinary bladder) as well as in 230 squamous cell carcinomas of various organs of origin $(\mathrm{n}=8)$, but all derived from squamous epithelia that are normally CK18 negative (Table 2, Fig. 4). Reduced or absent CK18 immunostaining was associated with high UICC stage $(\mathrm{p}=0.0010)$, high Thoenes grade $(\mathrm{p}=0.0086)$, advanced tumor stage $(\mathrm{p}<0.0001)$, and poor prognosis in clear cell renal cell cancers $(\mathrm{p}=0.0088)$ and with high grade and unfavorable molecular features such as ER/PR negativity $(\mathrm{p}<0.0001$ each) - but not with patient outcome-in invasive breast carcinomas of no special type. In squamous cell carcinomas, CK18 up-regulation was preferentially seen in cancers with advanced stage $(13.2 \% / 136$ pT1-2 vs $27.7 \% / 94$ pT3-4; $\mathrm{p}=0.0154)$, presence of lymph node metastasis $(14.7 \% / 95$ pN0 vs $26.1 \% / 92 ; \mathrm{p}=0.0354)$ and high grade $(14.9 \% / 134 \mathrm{G} 1-2$ vs $28.0 \% / 75$ G3; $p=0.0767$, data not shown). In bladder cancer, the CK18 expression pattern varied between subgroups. Within 1,353 patients that were treated by cystectomy, CK18 expression was unrelated to pathological parameters and patient outcome, however.

\section{Discussion}

The standardized analysis of 11,952 cancers by IHC gives a comprehensive overview on CK18 staining in malignant tumors. The most valuable result of our study is a ranking order of CK18 positivity across a broad range of tumor entities which enables an estimate of the relative biologic importance of CK18 for individual tumor types and-together with the absolute numbers obtained in our analysis-a better assessment of the diagnostic impact of CK18 immunostaining results in specific diagnostic situations. The S-shaped curve of the CK18 expression frequencies found across 115 different tumor types reflects that frequent and intense CK18 immunostaining is commonly seen in cancers derived from CK18 positive normal cell types while most other tumors are often CK18 negative. 37 of 115 analyzed tumor entities (32.2\%) showed CK18 positivity in $>97 \%$ of cases. Sporadic negative cases in the range of $\leq 3 \%$ in these cancer types may well be caused by technical issues. Some unexpected negative staining always occurs in TMAs because not all tissues are properly fixed in all areas (Tapia et al. 2004). Unequal immunostaining in tissues results in an 

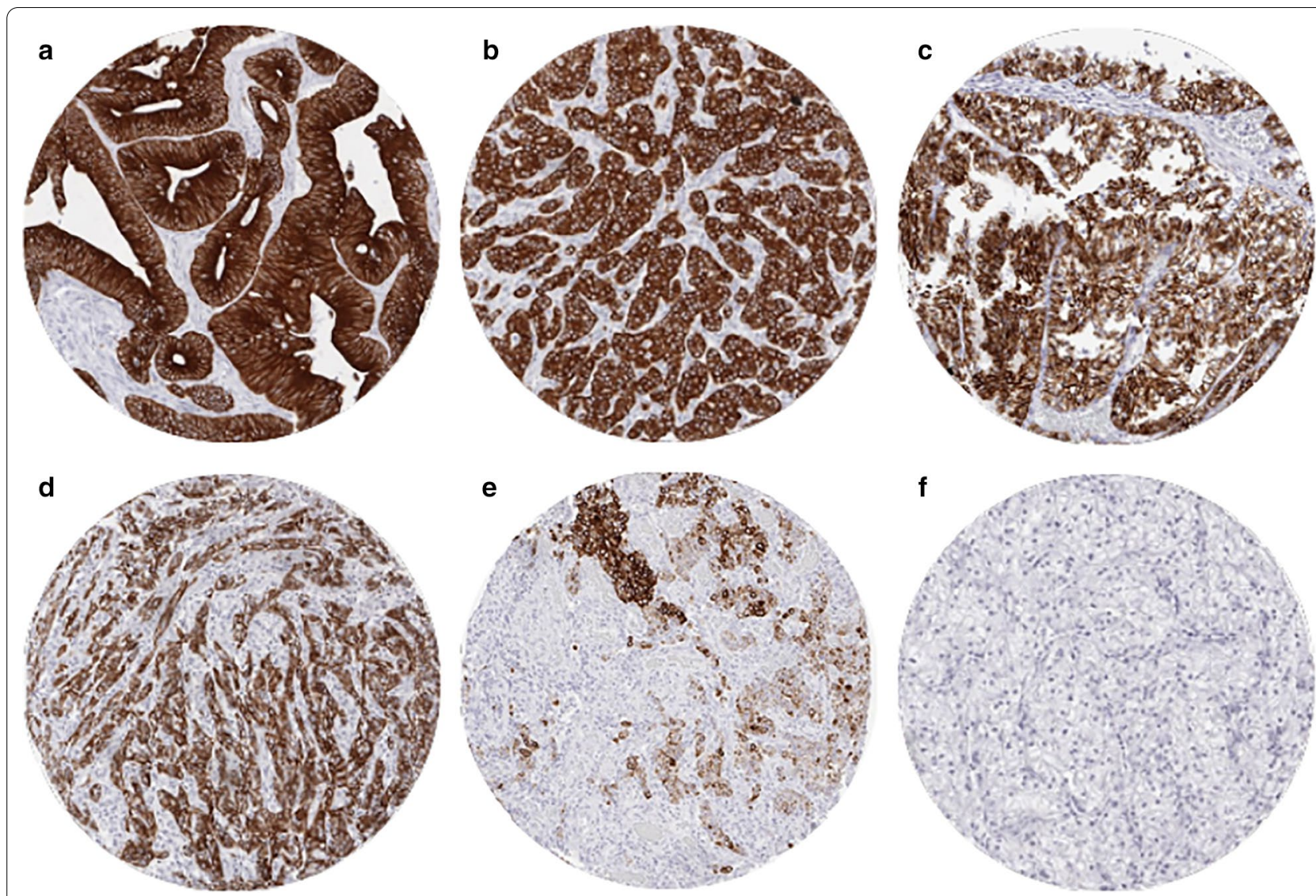

Fig. 2 Cytokeratin 18 (CK18) expression in tumors. The images show diffuse strong CK18 staining in a colorectal carcinoma (a), an invasive breast carcinoma of no special type (b), a clear cell carcinoma of the kidney (c), and a squamous cell carcinoma of the cervix uteri (d). CK18 immunostaining is focal in a squamous cell carcinoma of the larynx (e) and absent in another renal cell clear cell carcinoma (f)

immunostaining gradient across a tissue block and can result in false negative immunostaining, if TMA cores are taken from areas with poor reactivity (Fraune et al. 2020).

The group of cancers with variable CK18 immunostaining results including significant fractions of patients with CK18 positive and CK18 negative cancers, is heterogeneous in nature. This category contains cancer types arising from CK18 positive precursor cells but showing CK18 downregulation in a fraction of cases, tumor types arising from CK18 negative precursor cells but undergoing CK18 upregulation in a fraction of cancers, neoplasia's derived from tissues with variable CK18 expression in benign precursors, and tumors with a mixed differentiation. The latter group contains tumors with a mixed glandular/squamous differentiation such as endometroid carcinomas of the uterus where adenomatous but not squamous epithelia stain positive as well as epithelialmesenchymal tumors such as carcinosarcoma of the uterus and ovary, phyllodes tumor of the breast, teratoma of the testis or malignant mesothelioma. In these tumors, glandular epithelial but not mesenchymal tumor areas stain positive.

Cancers that markedly downregulate CK18 in a relevant fraction of cases include renal cell and breast cancers. True downregulation can easily be distinguished from artificial staining deficiency by presence of strongly staining normal cells in the same tissue spot. The analysis of larger cohorts of kidney and breast cancers for which clinical follow-up data were available identified significant associations of reduced CK18 immunostaining with unfavorable tumor phenotype and-in case of clear cell renal cell carcinoma-poor patient prognosis. These findings are consistent with earlier studies in breast cancer and may reflect a tendency towards a worse prognosis in cancer cells with an impaired cell differentiation (Woelfle et al. 2004; Willipinski-Stapelfeldt et al. 2005). That various cancers types that are by default poorly differentiated such as small cell carcinomas or anaplastic thyroid cancer showed lower CK18 positivity rates than their better differentiated counterparts is also consistent with the concept of a CK18 expression loss during tumor progression. 
Table 1 Cytokeratin 18 immunostaining in human tumors

\begin{tabular}{|c|c|c|c|c|c|c|c|c|}
\hline & \multirow[t]{2}{*}{ Entity } & \multirow[t]{2}{*}{ On TMA (n) } & \multicolumn{6}{|c|}{ CK18 immunostaining } \\
\hline & & & Analyzable (n) & Negative (\%) & Weak (\%) & Moderate (\%) & Strong (\%) & Positive (\%) \\
\hline \multirow[t]{6}{*}{ Tumors of the skin } & Pilomatrixoma & 35 & 28 & 100.0 & 0.0 & 0.0 & 0.0 & 0.0 \\
\hline & Basal cell carcinoma & 48 & 42 & 100.0 & 0.0 & 0.0 & 0.0 & 0.0 \\
\hline & Benign nevus & 29 & 23 & 100.0 & 0.0 & 0.0 & 0.0 & 0.0 \\
\hline & $\begin{array}{l}\text { Squamous cell carci- } \\
\text { noma of the skin }\end{array}$ & 50 & 44 & 93.2 & 6.8 & 0.0 & 0.0 & 6.8 \\
\hline & Malignant melanoma & 48 & 43 & 100.0 & 0.0 & 0.0 & 0.0 & 0.0 \\
\hline & Merkel cell carcinoma & 46 & 43 & 32.6 & 16.3 & 23.3 & 27.9 & 67.4 \\
\hline \multirow[t]{5}{*}{$\begin{array}{l}\text { Tumors of the head } \\
\text { and neck }\end{array}$} & $\begin{array}{l}\text { Squamous cell carci- } \\
\text { noma of the larynx }\end{array}$ & 50 & 43 & 72.1 & 25.6 & 0.0 & 2.3 & 27.9 \\
\hline & $\begin{array}{l}\text { Oral squamous cell } \\
\text { carcinoma (floor of } \\
\text { the mouth) }\end{array}$ & 50 & 43 & 93.0 & 7.0 & 0.0 & 0.0 & 7.0 \\
\hline & $\begin{array}{l}\text { Pleomorphic } \\
\text { adenoma of the } \\
\text { parotid gland }\end{array}$ & 50 & 42 & 23.8 & 50.0 & 19.0 & 7.1 & 76.2 \\
\hline & $\begin{array}{l}\text { Warthin tumor of the } \\
\text { parotid gland }\end{array}$ & 49 & 47 & 0.0 & 40.4 & 36.2 & 23.4 & 100.0 \\
\hline & $\begin{array}{l}\text { Basal cell adenoma of } \\
\text { the salivary gland }\end{array}$ & 15 & 15 & 6.7 & 60.0 & 6.7 & 26.7 & 93.3 \\
\hline \multirow[t]{6}{*}{$\begin{array}{l}\text { Tumors of the lung, } \\
\text { pleura and thymus }\end{array}$} & $\begin{array}{l}\text { Adenocarcinoma of } \\
\text { the lung }\end{array}$ & 200 & 176 & 0.0 & 29.5 & 28.4 & 42.0 & 100.0 \\
\hline & $\begin{array}{c}\text { Squamous cell carci- } \\
\text { noma of the lung }\end{array}$ & 77 & 66 & 39.4 & 48.5 & 7.6 & 4.5 & 60.6 \\
\hline & $\begin{array}{l}\text { Small cell carcinoma } \\
\text { of the lung }\end{array}$ & 20 & 16 & 18.8 & 12.5 & 50.0 & 18.8 & 81.3 \\
\hline & $\begin{array}{l}\text { Malignant mesothe- } \\
\text { lioma }\end{array}$ & 48 & 40 & 12.5 & 12.5 & 15.0 & 60.0 & 87.5 \\
\hline & $\begin{array}{l}\text { Mesothelioma, other } \\
\text { types }\end{array}$ & 28 & 18 & 11.1 & 33.3 & 16.7 & 38.9 & 88.9 \\
\hline & $\begin{array}{l}\text { Mesothelioma, } \\
\text { epitheloid }\end{array}$ & 39 & 26 & 3.8 & 11.5 & 34.6 & 50.0 & 96.2 \\
\hline \multirow[t]{11}{*}{$\begin{array}{l}\text { Tumors of the female } \\
\text { genital tract }\end{array}$} & $\begin{array}{l}\text { Squamous cell } \\
\text { carcinoma of the } \\
\text { vagina }\end{array}$ & 48 & 20 & 90.0 & 5.0 & 0.0 & 5.0 & 10.0 \\
\hline & $\begin{array}{l}\text { Squamous cell carci- } \\
\text { noma of the vulva }\end{array}$ & 50 & 33 & 100.0 & 0.0 & 0.0 & 0.0 & 0.0 \\
\hline & $\begin{array}{c}\text { Squamous cell carci- } \\
\text { noma of the cervix }\end{array}$ & 50 & 35 & 88.6 & 2.9 & 0.0 & 8.6 & 11.4 \\
\hline & $\begin{array}{l}\text { Adenocarcinoma of } \\
\text { the cervix uteri }\end{array}$ & 50 & 38 & 0.0 & 13.2 & 23.7 & 63.2 & 100.0 \\
\hline & $\begin{array}{l}\text { Endometrioid endo- } \\
\text { metrial carcinoma }\end{array}$ & 236 & 212 & 0.5 & 14.2 & 22.2 & 63.2 & 99.5 \\
\hline & $\begin{array}{l}\text { Endometrial serous } \\
\text { carcinoma }\end{array}$ & 82 & 53 & 1.9 & 15.1 & 34.0 & 43.4 & 92.5 \\
\hline & $\begin{array}{l}\text { Carcinosarcoma of } \\
\text { the uterus }\end{array}$ & 48 & 38 & 21.1 & 26.3 & 34.2 & 18.4 & 78.9 \\
\hline & $\begin{array}{l}\text { Endometrial clear cell } \\
\text { carcinoma }\end{array}$ & 8 & 7 & 0.0 & 57.1 & 42.9 & 0.0 & 100.0 \\
\hline & $\begin{array}{l}\text { Endometrial } \\
\text { carcinoma, low dif- } \\
\text { ferentiated G3 }\end{array}$ & 13 & 12 & 33.3 & 33.3 & 25.0 & 8.3 & 66.7 \\
\hline & $\begin{array}{l}\text { Endometrial stromal } \\
\text { sarcoma }\end{array}$ & 12 & 10 & 100.0 & 0.0 & 0.0 & 0.0 & 0.0 \\
\hline & $\begin{array}{l}\text { Endometrioid carci- } \\
\text { noma of the ovary }\end{array}$ & 115 & 86 & 1.2 & 4.7 & 26.7 & 67.4 & 98.8 \\
\hline
\end{tabular}


Table 1 (continued)

\begin{tabular}{|c|c|c|c|c|c|c|c|c|}
\hline & \multirow[t]{2}{*}{ Entity } & \multirow[t]{2}{*}{ On TMA (n) } & \multicolumn{6}{|c|}{ CK18 immunostaining } \\
\hline & & & Analyzable (n) & Negative (\%) & Weak (\%) & Moderate (\%) & Strong (\%) & Positive (\%) \\
\hline & $\begin{array}{l}\text { Serous carcinoma of } \\
\text { the ovary }\end{array}$ & 567 & 495 & 0.8 & 13.7 & 31.9 & 53.5 & 99.2 \\
\hline & $\begin{array}{l}\text { Mucinous carcinoma } \\
\text { of the ovary }\end{array}$ & 97 & 75 & 0.0 & 17.3 & 18.7 & 64.0 & 100.0 \\
\hline & $\begin{array}{l}\text { Clear cell carcinoma } \\
\text { of the ovary }\end{array}$ & 54 & 47 & 8.5 & 34.0 & 31.9 & 25.5 & 91.5 \\
\hline & $\begin{array}{l}\text { Carcinosarcoma of } \\
\text { the ovary }\end{array}$ & 47 & 41 & 22.0 & 14.6 & 24.4 & 39.0 & 78.0 \\
\hline & Brenner tumor & 9 & 8 & 62.5 & 37.5 & 0.0 & 0.0 & 37.5 \\
\hline \multirow[t]{6}{*}{ Tumors of the breast } & $\begin{array}{l}\text { Invasive breast carci- } \\
\text { noma of no special } \\
\text { type }\end{array}$ & 1391 & 1001 & 3.6 & 21.8 & 23.5 & 50.9 & 96.2 \\
\hline & $\begin{array}{l}\text { Lobular carcinoma of } \\
\text { the breast }\end{array}$ & 294 & 229 & 0.4 & 21.0 & 26.6 & 52.0 & 99.6 \\
\hline & $\begin{array}{l}\text { Medullary carcinoma } \\
\text { of the breast }\end{array}$ & 26 & 22 & 59.1 & 18.2 & 9.1 & 13.6 & 40.9 \\
\hline & $\begin{array}{l}\text { Tubular carcinoma of } \\
\text { the breast }\end{array}$ & 27 & 17 & 0.0 & 23.5 & 17.6 & 58.8 & 100.0 \\
\hline & $\begin{array}{l}\text { Mucinous carcinoma } \\
\text { of the breast }\end{array}$ & 58 & 35 & 0.0 & 11.4 & 37.1 & 51.4 & 100.0 \\
\hline & $\begin{array}{l}\text { Phyllodes tumor of } \\
\text { the breast }\end{array}$ & 50 & 32 & 0.0 & 37.5 & 21.9 & 40.6 & 100.0 \\
\hline \multirow[t]{15}{*}{$\begin{array}{l}\text { Tumors of the diges- } \\
\text { tive system }\end{array}$} & $\begin{array}{l}\text { Adenomatous polyp, } \\
\text { low-grade dysplasia }\end{array}$ & 50 & 41 & 0.0 & 0.0 & 0.0 & 100.0 & 100.0 \\
\hline & $\begin{array}{l}\text { Adenomatous } \\
\text { polyp, high-grade } \\
\text { dysplasia }\end{array}$ & 50 & 44 & 0.0 & 0.0 & 2.3 & 97.7 & 100.0 \\
\hline & $\begin{array}{l}\text { Adenocarcinoma of } \\
\text { the colon }\end{array}$ & 1932 & 1750 & 2.6 & 2.3 & 9.9 & 85.3 & 97.4 \\
\hline & $\begin{array}{l}\text { Adenocarcinoma of } \\
\text { the small intestine }\end{array}$ & 10 & 5 & 0.0 & 0.0 & 0.0 & 100.0 & 100.0 \\
\hline & $\begin{array}{l}\text { Gastric adenocarci- } \\
\text { noma, diffuse type }\end{array}$ & 226 & 161 & 5.6 & 32.3 & 28.6 & 33.5 & 94.4 \\
\hline & $\begin{array}{l}\text { Gastric adenocarci- } \\
\text { noma, intestinal } \\
\text { type }\end{array}$ & 224 & 156 & 7.1 & 23.7 & 19.2 & 50.0 & 92.9 \\
\hline & $\begin{array}{l}\text { Gastric adenocarci- } \\
\text { noma, mixed type }\end{array}$ & 62 & 59 & 5.1 & 25.4 & 22.0 & 47.5 & 94.9 \\
\hline & $\begin{array}{l}\text { Adenocarcinoma of } \\
\text { the esophagus }\end{array}$ & 133 & 70 & 1.4 & 12.9 & 7.1 & 78.6 & 98.6 \\
\hline & $\begin{array}{l}\text { Squamous cell } \\
\text { carcinoma of the } \\
\text { esophagus }\end{array}$ & 124 & 63 & 68.3 & 22.2 & 0.0 & 9.5 & 31.7 \\
\hline & $\begin{array}{l}\text { Squamous cell } \\
\text { carcinoma of the } \\
\text { anal canal }\end{array}$ & 50 & 33 & 75.8 & 15.2 & 9.1 & 0.0 & 24.2 \\
\hline & Cholangiocarcinoma & 130 & 112 & 1.8 & 17.0 & 29.5 & 51.8 & 98.2 \\
\hline & $\begin{array}{l}\text { Hepatocellular carci- } \\
\text { noma }\end{array}$ & 50 & 49 & 8.2 & 28.6 & 20.4 & 42.9 & 91.8 \\
\hline & $\begin{array}{l}\text { Ductal adenocar- } \\
\text { cinoma of the } \\
\text { pancreas }\end{array}$ & 612 & 523 & 1.0 & 16.8 & 25.6 & 56.6 & 99.0 \\
\hline & $\begin{array}{l}\text { Pancreatic/Ampullary } \\
\text { adenocarcinoma }\end{array}$ & 89 & 76 & 5.3 & 6.6 & 25.0 & 63.2 & 94.7 \\
\hline & $\begin{array}{l}\text { Acinar cell carcinoma } \\
\text { of the pancreas }\end{array}$ & 13 & 12 & 0.0 & 0.0 & 16.7 & 83.3 & 100.0 \\
\hline
\end{tabular}


Table 1 (continued)

\begin{tabular}{|c|c|c|c|c|c|c|c|c|}
\hline & \multirow[t]{2}{*}{ Entity } & \multirow[t]{2}{*}{ On TMA (n) } & \multicolumn{6}{|c|}{ CK18 immunostaining } \\
\hline & & & Analyzable (n) & Negative (\%) & Weak (\%) & Moderate (\%) & Strong (\%) & Positive (\%) \\
\hline & $\begin{array}{l}\text { Gastrointestinal stro- } \\
\text { mal tumor (GIST) }\end{array}$ & 50 & 42 & 97.6 & 2.4 & 0.0 & 0.0 & 2.4 \\
\hline \multirow[t]{11}{*}{$\begin{array}{l}\text { Tumors of the urinary } \\
\text { system }\end{array}$} & $\begin{array}{l}\text { Non-invasive } \\
\text { papillary urothelial } \\
\text { carcinoma, pTa G2 } \\
\text { low grade }\end{array}$ & 177 & 109 & 41.3 & 11.9 & 23.9 & 22.9 & 58.7 \\
\hline & $\begin{array}{l}\text { Non-invasive } \\
\text { papillary urothelial } \\
\text { carcinoma, pTa G2 } \\
\text { high grade }\end{array}$ & 141 & 100 & 36.0 & 20.0 & 24.0 & 20.0 & 64.0 \\
\hline & $\begin{array}{l}\text { Non-invasive papil- } \\
\text { lary urothelial carci- } \\
\text { noma, pTa G3 }\end{array}$ & 187 & 144 & 18.8 & 27.8 & 24.3 & 29.2 & 81.3 \\
\hline & $\begin{array}{l}\text { Urothelial carcinoma, } \\
\text { pT2-4 G3 }\end{array}$ & 1164 & 939 & 39.7 & 28.1 & 14.7 & 17.5 & 60.3 \\
\hline & $\begin{array}{l}\text { Small cell neuroen- } \\
\text { docrine carcinoma } \\
\text { of the bladder }\end{array}$ & 18 & 18 & 33.3 & 33.3 & 11.1 & 22.2 & 66.7 \\
\hline & $\begin{array}{l}\text { Sarcomatoid urothe- } \\
\text { lial carcinoma }\end{array}$ & 25 & 18 & 66.7 & 33.3 & 0.0 & 0.0 & 33.3 \\
\hline & $\begin{array}{l}\text { Clear cell renal cell } \\
\text { carcinoma }\end{array}$ & 858 & 722 & 47.5 & 31.2 & 14.3 & 7.1 & 52.5 \\
\hline & $\begin{array}{l}\text { Papillary renal cell } \\
\text { carcinoma }\end{array}$ & 255 & 209 & 2.4 & 15.3 & 15.8 & 66.0 & 97.1 \\
\hline & $\begin{array}{l}\text { Chromophobe renal } \\
\text { cell carcinoma }\end{array}$ & 131 & 112 & 0.9 & 9.8 & 20.5 & 68.8 & 99.1 \\
\hline & Oncocytoma & 177 & 144 & 1.4 & 11.8 & 16.7 & 69.4 & 97.9 \\
\hline & $\begin{array}{l}\text { Clear cell (tubulo) } \\
\text { papillary renal cell } \\
\text { carcinoma }\end{array}$ & 21 & 18 & 27.8 & 5.6 & 16.7 & 50.0 & 72.2 \\
\hline \multirow[t]{10}{*}{$\begin{array}{l}\text { Tumors of the male } \\
\text { genital organs }\end{array}$} & $\begin{array}{l}\text { Adenocarcinoma } \\
\text { of the prostate, } \\
\text { Gleason } 3+3\end{array}$ & 83 & 82 & 0.0 & 1.2 & 1.2 & 97.6 & 100.0 \\
\hline & $\begin{array}{l}\text { Adenocarcinoma } \\
\text { of the prostate, } \\
\text { Gleason } 4+4\end{array}$ & 80 & 73 & 0.0 & 4.1 & 1.4 & 94.5 & 100.0 \\
\hline & $\begin{array}{l}\text { Adenocarcinoma } \\
\text { of the prostate, } \\
\text { Gleason } 5+5\end{array}$ & 85 & 81 & 0.0 & 3.7 & 11.1 & 85.2 & 100.0 \\
\hline & $\begin{array}{l}\text { Adenocarcinoma of } \\
\text { the prostate (recur- } \\
\text { rence) }\end{array}$ & 330 & 287 & 6.3 & 16.0 & 27.9 & 49.8 & 93.7 \\
\hline & $\begin{array}{l}\text { Small cell neuroen- } \\
\text { docrine carcinoma } \\
\text { of the prostate }\end{array}$ & 17 & 16 & 25.0 & 18.8 & 37.5 & 18.8 & 75.0 \\
\hline & Seminoma & 220 & 204 & 97.5 & 2.5 & 0.0 & 0.0 & 2.5 \\
\hline & $\begin{array}{l}\text { Germ cell neoplasia } \\
\text { in situ }\end{array}$ & 85 & 67 & 64.2 & 29.9 & 3.0 & 3.0 & 35.8 \\
\hline & $\begin{array}{l}\text { Embryonal carcinoma } \\
\text { of the testis }\end{array}$ & 50 & 46 & 0.0 & 23.9 & 19.6 & 56.5 & 100.0 \\
\hline & Yolk sack tumor & 50 & 42 & 0.0 & 38.1 & 21.4 & 40.5 & 100.0 \\
\hline & Teratoma & 50 & 27 & 70.4 & 14.8 & 0.0 & 14.8 & 29.6 \\
\hline \multirow[t]{2}{*}{$\begin{array}{l}\text { Tumors of endocrine } \\
\text { organs }\end{array}$} & $\begin{array}{l}\text { Adenoma of the } \\
\text { thyroid gland }\end{array}$ & 114 & 109 & 0.0 & 5.5 & 35.8 & 58.7 & 100.0 \\
\hline & $\begin{array}{l}\text { Papillary thyroid } \\
\text { carcinoma }\end{array}$ & 392 & 381 & 0.3 & 1.6 & 14.7 & 83.5 & 99.7 \\
\hline
\end{tabular}


Table 1 (continued)

\begin{tabular}{|c|c|c|c|c|c|c|c|c|}
\hline & \multirow[t]{2}{*}{ Entity } & \multirow[t]{2}{*}{ On TMA (n) } & \multicolumn{6}{|c|}{ CK18 immunostaining } \\
\hline & & & Analyzable (n) & Negative (\%) & Weak (\%) & Moderate (\%) & Strong (\%) & Positive (\%) \\
\hline & $\begin{array}{l}\text { Follicular thyroid } \\
\text { carcinoma }\end{array}$ & 158 & 150 & 0.0 & 2.0 & 34.0 & 64.0 & 100.0 \\
\hline & $\begin{array}{l}\text { Medullary thyroid } \\
\text { carcinoma }\end{array}$ & 107 & 98 & 1.0 & 6.1 & 33.7 & 59.2 & 99.0 \\
\hline & $\begin{array}{l}\text { Anaplastic thyroid } \\
\text { carcinoma }\end{array}$ & 45 & 43 & 41.9 & 32.6 & 14.0 & 11.6 & 58.1 \\
\hline & $\begin{array}{l}\text { Adrenal cortical } \\
\text { adenoma }\end{array}$ & 50 & 36 & 91.7 & 5.6 & 0.0 & 2.8 & 8.3 \\
\hline & $\begin{array}{l}\text { Adrenal cortical } \\
\text { carcinoma }\end{array}$ & 26 & 20 & 70.0 & 10.0 & 0.0 & 20.0 & 30.0 \\
\hline & Phaeochromocytoma & 50 & 42 & 100.0 & 0.0 & 0.0 & 0.0 & 0.0 \\
\hline & $\begin{array}{l}\text { Appendix, neuroen- } \\
\text { docrine tumor } \\
\text { (NET) }\end{array}$ & 22 & 15 & 0.0 & 8.3 & 0.0 & 91.7 & 100.0 \\
\hline & $\begin{array}{l}\text { Colorectal, neuroen- } \\
\text { docrine tumor } \\
\text { (NET) }\end{array}$ & 10 & 10 & 0.0 & 0.0 & 10.0 & 90.0 & 100.0 \\
\hline & $\begin{array}{l}\text { Ileum, neuroendo- } \\
\text { crine tumor (NET) }\end{array}$ & 49 & 45 & 0.0 & 2.2 & 2.2 & 95.6 & 100.0 \\
\hline & $\begin{array}{l}\text { Lung, neuroendo- } \\
\text { crine tumor (NET) }\end{array}$ & 19 & 18 & 0.0 & 11.8 & 17.6 & 70.6 & 100.0 \\
\hline & $\begin{array}{l}\text { Pancreas, neuroendo- } \\
\text { crine tumor (NET) }\end{array}$ & 102 & 79 & 1.3 & 5.1 & 31.6 & 62.0 & 98.7 \\
\hline & $\begin{array}{l}\text { Colorectal, neuroen- } \\
\text { docrine carcinoma } \\
\text { (NEC) }\end{array}$ & 11 & 9 & 33.3 & 22.2 & 22.2 & 22.2 & 66.7 \\
\hline & $\begin{array}{l}\text { Gallbladder, neuroen- } \\
\text { docrine carcinoma } \\
\text { (NEC) }\end{array}$ & 4 & 4 & 50.0 & 0.0 & 25.0 & 25.0 & 50.0 \\
\hline & $\begin{array}{l}\text { Pancreas, neuroen- } \\
\text { docrine carcinoma } \\
\text { (NEC) }\end{array}$ & 13 & 7 & 28.6 & 28.6 & 0.0 & 42.9 & 71.4 \\
\hline \multirow{2}{*}{$\begin{array}{l}\text { Tumors of hae- } \\
\text { motopoetic and } \\
\text { lymphoid tissues }\end{array}$} & Hodgkin Lymphoma & 45 & 39 & 100.0 & 0.0 & 0.0 & 0.0 & 0.0 \\
\hline & $\begin{array}{l}\text { Non-Hodgkin Lym- } \\
\text { phoma }\end{array}$ & 48 & 41 & 100.0 & 0.0 & 0.0 & 0.0 & 0.0 \\
\hline \multirow[t]{13}{*}{$\begin{array}{l}\text { Tumors of soft tissue } \\
\text { and bone }\end{array}$} & $\begin{array}{l}\text { Tenosynovial giant } \\
\text { cell tumor }\end{array}$ & 45 & 43 & 100.0 & 0.0 & 0.0 & 0.0 & 0.0 \\
\hline & Granular cell tumor & 53 & 32 & 100.0 & 0.0 & 0.0 & 0.0 & 0.0 \\
\hline & Leiomyoma & 50 & 32 & 100.0 & 0.0 & 0.0 & 0.0 & 0.0 \\
\hline & Angiomyolipoma & 91 & 74 & 98.6 & 1.4 & 0.0 & 0.0 & 1.4 \\
\hline & Angiosarcoma & 73 & 55 & 87.3 & 7.3 & 3.6 & 1.8 & 12.7 \\
\hline & $\begin{array}{l}\text { Dermatofibrosar- } \\
\text { coma protuberans }\end{array}$ & 21 & 16 & 100.0 & 0.0 & 0.0 & 0.0 & 0.0 \\
\hline & Ganglioneuroma & 14 & 11 & 100.0 & 0.0 & 0.0 & 0.0 & 0.0 \\
\hline & Kaposi sarcoma & 8 & 5 & 100.0 & 0.0 & 0.0 & 0.0 & 0.0 \\
\hline & Leiomyosarcoma & 87 & 70 & 100.0 & 0.0 & 0.0 & 0.0 & 0.0 \\
\hline & Liposarcoma & 132 & 98 & 100.0 & 0.0 & 0.0 & 0.0 & 0.0 \\
\hline & $\begin{array}{l}\text { Malignant peripheral } \\
\text { nerve sheath tumor } \\
\text { (MPNST) }\end{array}$ & 13 & 12 & 100.0 & 0.0 & 0.0 & 0.0 & 0.0 \\
\hline & Myofibrosarcoma & 26 & 24 & 100.0 & 0.0 & 0.0 & 0.0 & 0.0 \\
\hline & Neurofibroma & 117 & 103 & 100.0 & 0.0 & 0.0 & 0.0 & 0.0 \\
\hline
\end{tabular}


Table 1 (continued)

\begin{tabular}{|c|c|c|c|c|c|c|c|}
\hline \multirow[t]{2}{*}{ Entity } & \multirow[t]{2}{*}{ On TMA (n) } & \multicolumn{6}{|c|}{ CK18 immunostaining } \\
\hline & & Analyzable (n) & Negative (\%) & Weak (\%) & Moderate (\%) & Strong (\%) & Positive (\%) \\
\hline $\begin{array}{l}\text { Sarcoma, not oth- } \\
\text { erwise specified } \\
\text { (NOS) }\end{array}$ & 75 & 67 & 94.0 & 4.5 & 1.5 & 0.0 & 6.0 \\
\hline Paraganglioma & 41 & 37 & 100.0 & 0.0 & 0.0 & 0.0 & 0.0 \\
\hline $\begin{array}{l}\text { Primitive neuroec- } \\
\text { todermal tumor } \\
\text { (PNET) }\end{array}$ & 23 & 13 & 100.0 & 0.0 & 0.0 & 0.0 & 0.0 \\
\hline Rhabdomyosarcoma & 7 & 6 & 100.0 & 0.0 & 0.0 & 0.0 & 0.0 \\
\hline Schwannoma & 121 & 93 & 98.9 & 0.0 & 1.1 & 0.0 & 1.1 \\
\hline Synovial sarcoma & 12 & 10 & 100.0 & 0.0 & 0.0 & 0.0 & 0.0 \\
\hline Osteosarcoma & 43 & 29 & 96.6 & 3.4 & 0.0 & 0.0 & 3.4 \\
\hline Chondrosarcoma & 39 & 21 & 100.0 & 0.0 & 0.0 & 0.0 & 0.0 \\
\hline
\end{tabular}

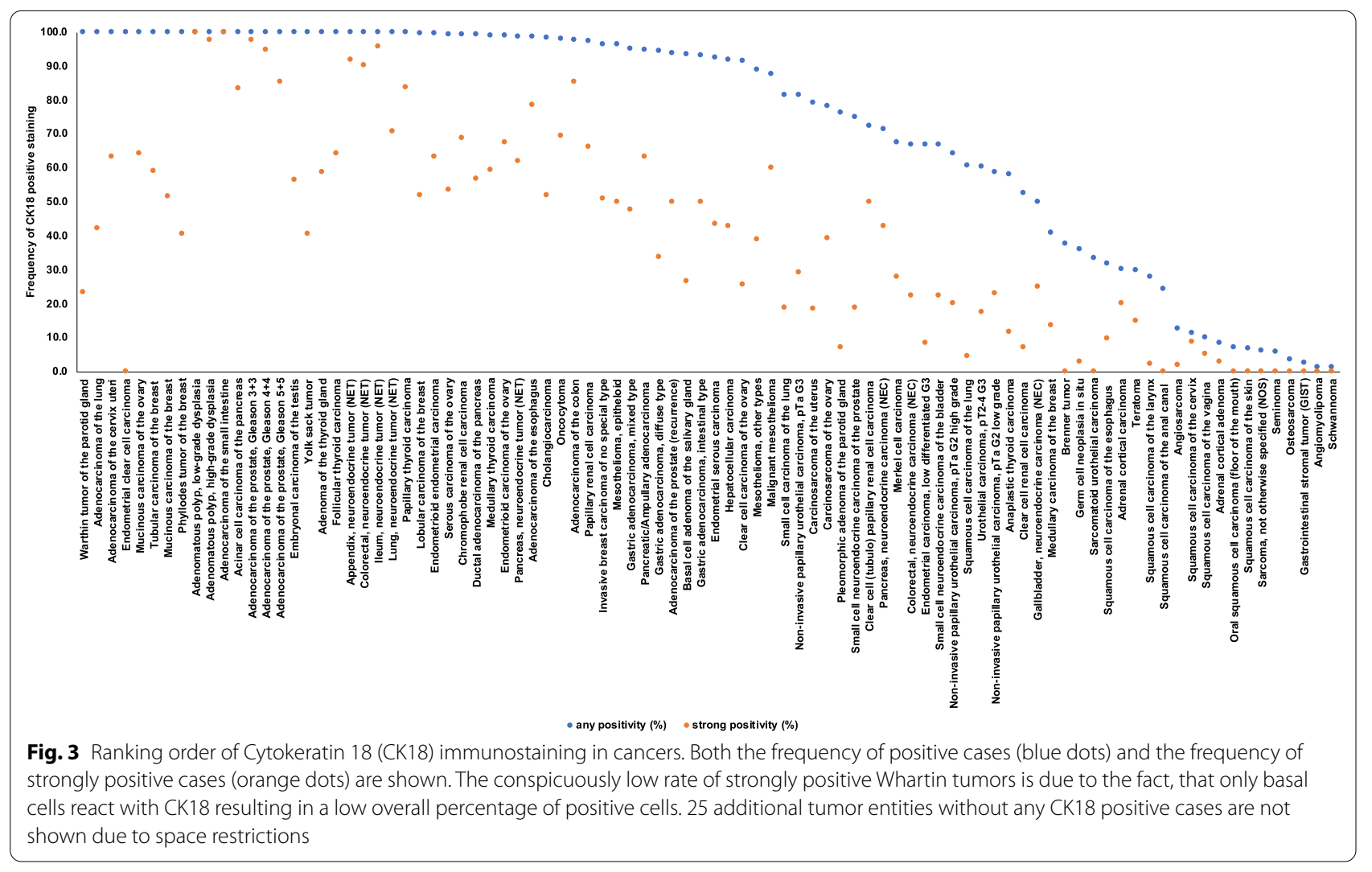

Squamous cell carcinomas are the best examples of epithelial tumors that are typically CK18 negative but can upregulate CK18. Even though CK18 immunostaining was not at all observed in any normal squamous epithelium samples from the lung, tonsil, skin, anal canal, oral cavity, or lip, a positive CK18 immunostaining was observed in 8 of 9 analyzed squamous cell carcinoma subtypes. That CK18 immunostaining was sometimes seen at high levels in these squamous cell carcinomas further demonstrates that these findings reflect true overexpression and not just a faint non-specific antibody binding. Our notion, that CK18 upregulation reflects aberrant differentiation or dedifferentiation in these cancers is supported by significant associations of elevated CK18 protein levels with high pT stage and presence of nodal metastasis that could be 
Table 2 Cytokeratin 18 immunostaining and tumor phenotype

\begin{tabular}{|c|c|c|c|c|c|c|}
\hline & \multirow[t]{2}{*}{ n } & \multicolumn{4}{|c|}{ CK18 Immunostaining } & \multirow[t]{2}{*}{$p$} \\
\hline & & Negative (\%) & Weak (\%) & Moderate (\%) & Strong (\%) & \\
\hline \multicolumn{7}{|c|}{$\begin{array}{l}\text { Invasive breast carcinoma of no } \\
\text { special type }\end{array}$} \\
\hline All cancers & 935 & 3.6 & 22.2 & 23.9 & 50.3 & \\
\hline pT1 & 497 & 4.2 & 18.9 & 25.0 & 51.9 & 0.0611 \\
\hline pT2 & 333 & 2.4 & 26.1 & 23.7 & 47.8 & \\
\hline pT3-4 & 73 & 6.9 & 19.2 & 16.4 & 57.5 & \\
\hline Grade 1 & 147 & 0.0 & 16.3 & 21.1 & 62.6 & $<0.0001$ \\
\hline Grade 2 & 479 & 2.1 & 19.0 & 26.7 & 52.2 & \\
\hline Grade 3 & 308 & 7.8 & 30.2 & 20.5 & 41.6 & \\
\hline pNO & 439 & 3.2 & 20.1 & 23.9 & 52.9 & 0.6092 \\
\hline $\mathrm{pN}+$ & 299 & 2.7 & 23.1 & 25.8 & 48.5 & \\
\hline HER2 negative & 697 & 4.0 & 20.8 & 22.0 & 53.2 & 0.1689 \\
\hline HER2 positive & 89 & 1.1 & 18.0 & 30.3 & 50.6 & \\
\hline ER negative & 160 & 15.0 & 33.8 & 23.1 & 28.1 & $<0.0001$ \\
\hline ER positive & 589 & 0.5 & 16.6 & 22.8 & 60.1 & \\
\hline PR negative & 308 & 8.8 & 28.6 & 24.0 & 38.6 & $<0.0001$ \\
\hline PR positive & 472 & 0.4 & 15.7 & 22.7 & 61.2 & \\
\hline Non-triple negative & 619 & 0.8 & 17.5 & 22.5 & 59.3 & $<0.0001$ \\
\hline Triple negative & 107 & 20.6 & 37.4 & 21.5 & 20.6 & \\
\hline \multicolumn{7}{|c|}{ Clear cell renal cell carcinoma } \\
\hline All cancers & 674 & 48.7 & 30.4 & 14.1 & 6.8 & \\
\hline ISUP 1 & 217 & 42.9 & 35.5 & 15.2 & 6.5 & 0.1312 \\
\hline ISUP 2 & 218 & 50.5 & 28.4 & 13.8 & 7.3 & \\
\hline ISUP 3 & 189 & 51.3 & 30.2 & 13.2 & 5.3 & \\
\hline ISUP 4 & 40 & 67.5 & 17.5 & 5.0 & 10.0 & \\
\hline Fuhrmann 1 & 32 & 37.5 & 34.4 & 21.9 & 6.3 & 0.2311 \\
\hline Fuhrmann 2 & 399 & 46.4 & 31.6 & 15.0 & 7.0 & \\
\hline Fuhrmann 3 & 194 & 52.1 & 30.9 & 11.3 & 5.7 & \\
\hline Fuhrmann 4 & 48 & 62.5 & 16.7 & 10.4 & 10.4 & \\
\hline Thoenes 1 & 239 & 41.0 & 33.9 & 17.6 & 7.5 & 0.0086 \\
\hline Thoenes 2 & 369 & 51.8 & 30.1 & 12.7 & 5.4 & \\
\hline Thoenes 3 & 65 & 60.0 & 20.0 & 7.7 & 12.3 & \\
\hline UICC 1 & 294 & 37.4 & 36.1 & 19.0 & 7.5 & 0.0010 \\
\hline UICC 2 & 34 & 50.0 & 32.4 & 11.8 & 5.9 & \\
\hline UICC 3 & 87 & 58.6 & 20.7 & 11.5 & 9.2 & \\
\hline UICC 4 & 70 & 57.1 & 34.3 & 7.1 & 1.4 & \\
\hline pT1 & 391 & 40.2 & 35.8 & 16.1 & 7.9 & $<0.0001$ \\
\hline pT2 & 72 & 59.7 & 25.0 & 11.1 & 4.2 & \\
\hline pT3 & 206 & 61.7 & 21.4 & 11.2 & 5.8 & \\
\hline pNO & 114 & 55.3 & 28.9 & 7.9 & 7.9 & 0.5327 \\
\hline $\mathrm{pN}+$ & 16 & 43.8 & 25.0 & 18.8 & 12.5 & \\
\hline pMo & 102 & 39.2 & 35.3 & 15.7 & 9.8 & $<0.0001$ \\
\hline $\mathrm{pM}+$ & 73 & 64.4 & 31.5 & 4.1 & 0.0 & \\
\hline \multicolumn{7}{|l|}{ Urinary bladder cancer } \\
\hline All cancers & 1353 & 37.0 & 25.4 & 18.0 & 19.7 & \\
\hline pTa G2 low & 109 & 41.3 & 11.9 & 23.9 & 22.9 & $<0.0001$ \\
\hline pTa G2 high & 100 & 36.0 & 20.0 & 24.0 & 20.0 & \\
\hline pTaG3 & 144 & 18.8 & 27.8 & 24.3 & 29.2 & \\
\hline
\end{tabular}


Table 2 (continued)

\begin{tabular}{|c|c|c|c|c|c|c|}
\hline & \multirow[t]{2}{*}{ n } & \multicolumn{4}{|c|}{ CK18 Immunostaining } & \multirow[t]{2}{*}{$p$} \\
\hline & & Negative (\%) & Weak (\%) & Moderate (\%) & Strong (\%) & \\
\hline $\mathrm{pT} \geq 2 \mathrm{G} 3$ & 921 & 39.9 & 28.0 & 14.8 & 17.4 & \\
\hline $\mathrm{pT} \geq 2 \mathrm{G} 3$ sarcomatoid & 18 & 33.3 & 33.3 & 11.1 & 22.2 & \\
\hline $\mathrm{p} T \geq 2 \mathrm{G} 3$ small cell cancer & 18 & 66.7 & 33.3 & 0.0 & 0.0 & \\
\hline $\mathrm{pNO}$ & 293 & 36.5 & 26.6 & 16.7 & 20.1 & 0.2540 \\
\hline $\mathrm{pN}+$ & 170 & 27.7 & 29.4 & 18.2 & 24.7 & \\
\hline
\end{tabular}
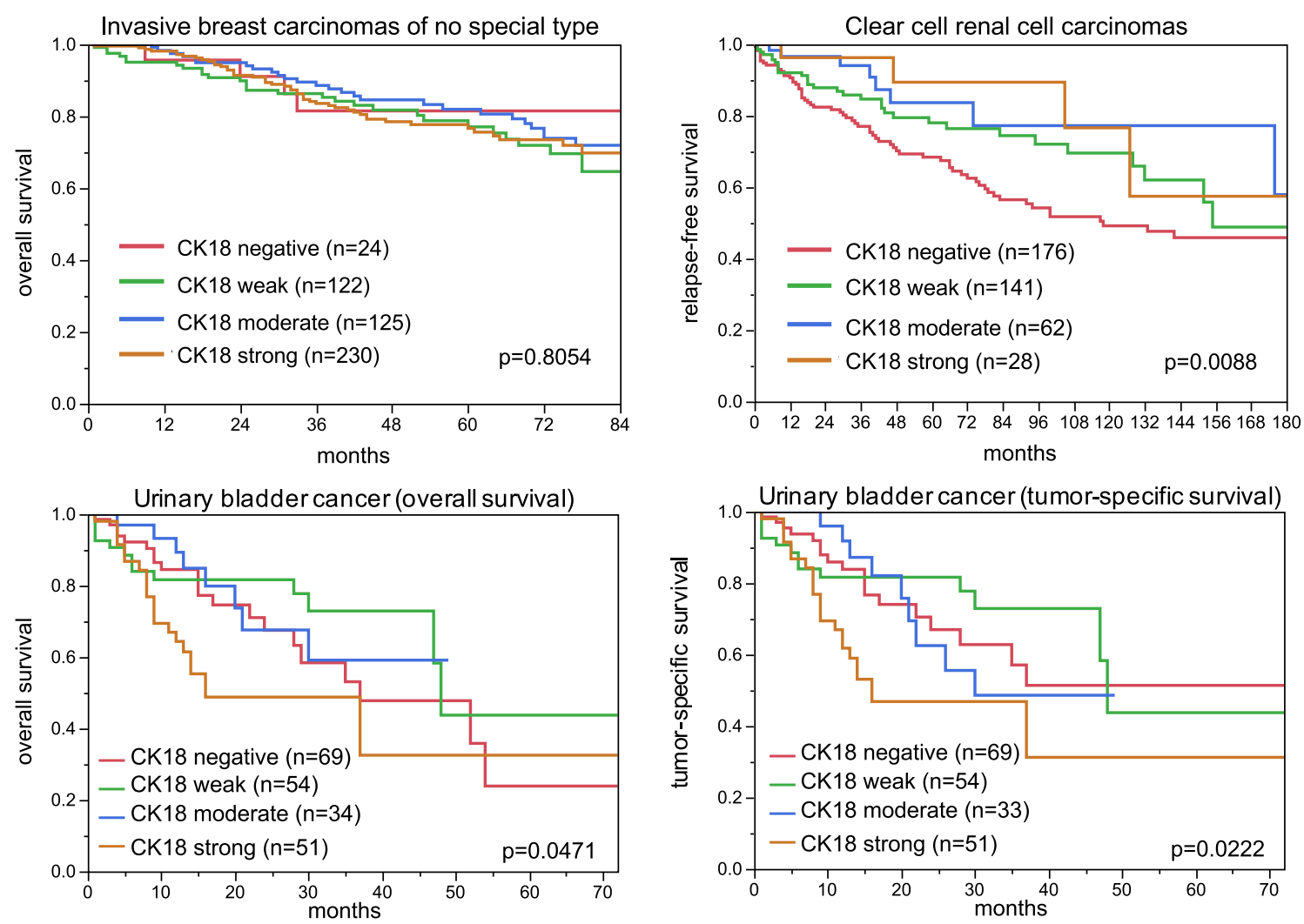

Fig. 4 Cytokeratin 18 (CK18) immunostaining and patient prognosis. All bladder cancer patients had at least pT2 cancers and were treated by cystectomy

identified in a combined analysis of our 230 squamous cell carcinomas with available clinico-pathological data. These findings fit with data from several earlier studies suggesting a link between CK18 positivity and unfavorable clinico-pathological features and outcome in squamous cell carcinomas of the lung, esophagus, oral cavity, and pharynx (Makino et al. 2009; Broers et al. 1988; Nanda et al. 2012; Nhung et al. 1999; Safadi et al. 2019; Yang et al. 2018; Afrem et al. 2016).
The role of CK18 is less clear in tumor entities derived from tissues with variable CK18 expression such as in liver and urinary bladder cancer. In our analysis of 1353 urothelial carcinomas, $37 \%$ were completely negative and $20 \%$ of all cancers were considered strongly positive. That a marked difference in CK18 immunostaining was seen between pTa and pT2-4 urothelial carcinomas is consistent with the striking genomic differences between these tumor categories (summarized in (Knowles and Hurst 2015)). The absence of a statistically significant impact 


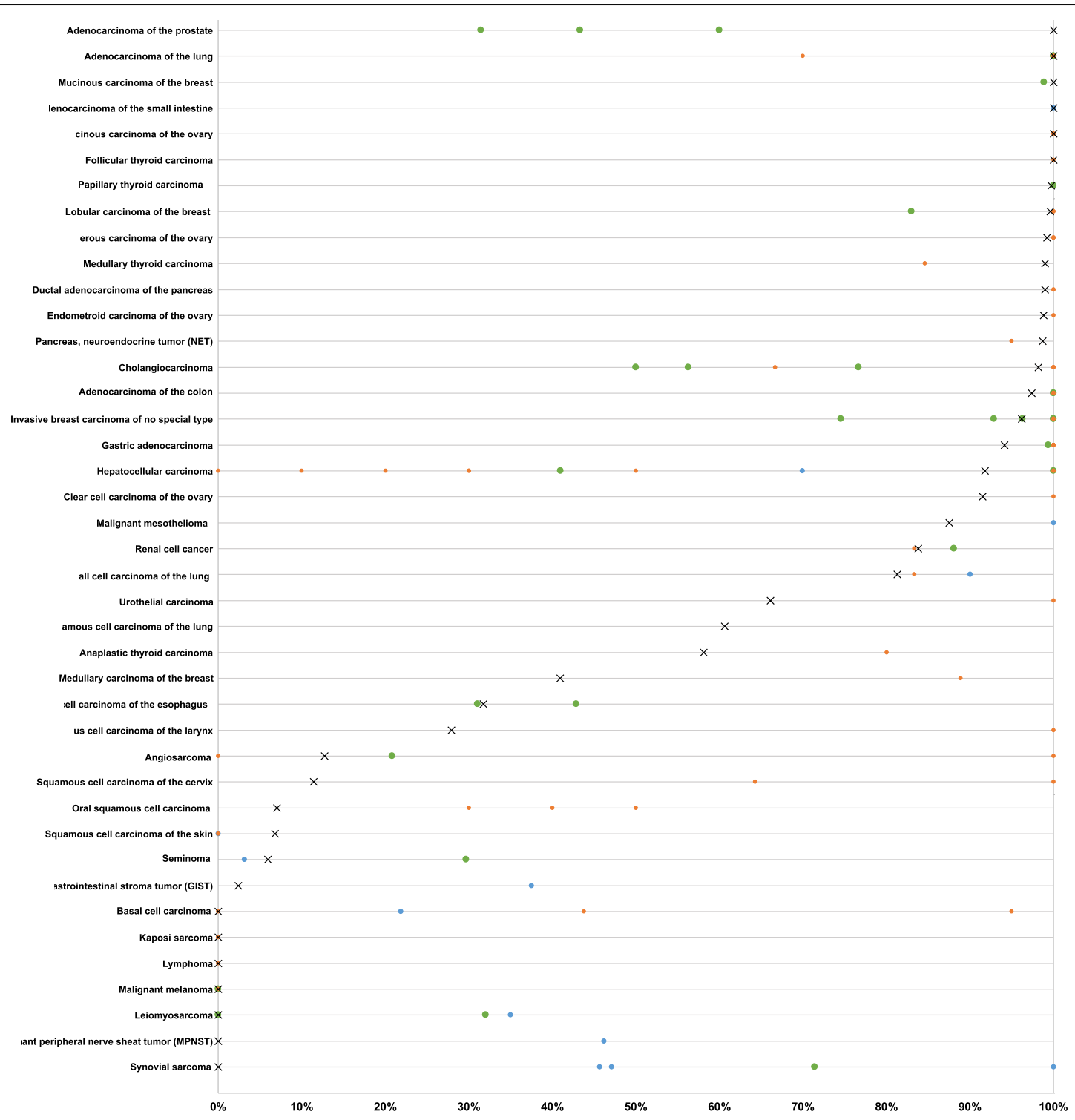

Fig. 5 Graphical comparison of Cytokeratin 18 (CK18) data from this study (x) in comparison with the previous literature. Orange dots are used for studies involving $\leq 20$ cases, green dots are used for studies $>20$ cases, blue dots are from Chu and Weiss 2002 (Review) (Chu and Weiss 2002). All studies are quoted in the list of references

of CK18 expression on clinico-pathological features and outcome of pT2-4 carcinomas treated by cystectomy argues against a functional role of CK18 for cancer progression. CK18 plays a role in various cellular processes, such as securing the structure of the cytoplasm and mitochondria that are not directly related to cancer aggressiveness (Coulombe and Wong 2004). Considering the continuous increase of CK18 expression from basal and intermediate cells to the superficial and umbrella cells of the bladder epithelium, various levels of CK18 in cancer cells may also be related to the specific cell of origin.
Our data enable a comprehensive assessment of potential diagnostic applications of CK18 IHC. The close to $100 \%$ prevalence of CK18 expression in gastrointestinal cancers supports the concept of using CK18 measurement for metastasis detection (Oshima et al. 1996; Makino et al. 2009). The most useful diagnostic application of CK18 IHC may be the distinction of seminomas from other germ cell tumors of the testis. Only 12 of 204 analyzed seminomas (6\%) but all of 88 embryonal carcinomas and yolk sack tumors of the testis showed CK18 expression. This finding is in line with data from an RNA and protein expression study identifying CK18 
as one of the strongest discriminators of seminomatous versus non-seminomatous testicular germ cell tumors (Biermann et al. 2007). Pan-cytokeratin antibodies are often being included in diagnostic IHC panels to be used for the distinction of testicular cancer subtypes. In this context, cytokeratin positivity argues against seminoma which ideally should show either none or only weak cytokeratin staining. Considering that pan-cytokeratin staining is found in $>20 \%$ of seminomas and in $>80 \%$ of non-seminomas (summarized in (Emerson and Ulbright (2005))), the use of cytokeratin 18 showing positivity in $2.5 \%$ of seminomas and $100 \%$ of embryonal carcinoma of the testis as well as $100 \%$ of yolk sack tumors in our study might be preferable for testicular cancer subtyping. It appears conceivable that an antibody targeting just CK18 offers better specificity than an antibody targeting multiple cytokeratins.

Importantly, all prevalence's described in this study are specific to the reagents and the protocol used in our laboratory. It is almost certain, that the use of different antibodies, protocols and interpretation criteria have jointly caused highly diverse literature data on CK18 expression in cancer (summarized in Fig. 5). It is well known, that different antibodies designed for the same target protein can vary to a large extent in their binding properties and that protocol modifications greatly impact the rate of immunostained cases (Saper 2009). However, the abundant data generated in this study would potentially make it possible to adjust a protocol for CK18 immunostaining and interpretation in a way that resulted in comparable frequencies of CK18 positivity. For that purpose, it might be sufficient to use smaller collections of tumors with high positivity rate such as adenocarcinomas of the prostate or the colorectum and of tumors with low positivity rates such as squamous cell carcinomas of various types to develop a protocol that results in comparable data as provided in this study.

\section{Conclusions}

Our data show that CK18 is consistently expressed in various epithelial cancers, especially adenocarcinomas. Both loss of CK18 expression in cancers derived from CK18 positive precursor cells and neo-expression in malignancies derived from CK18 positive precursors tend to be linked to unfavorable tumor phenotype and disease outcome. Distinction of seminomas from other germ cell tumors of the testis appears to be the strongest diagnostic application of CK18 IHC.

\section{Abbreviations}

Akt1: Serine/threonine-protein kinase; CK18: Cytokeratin 18; ER: Estrogen receptor; ERK: Extracellular signal-regulated kinase; IHC: Immunohistochemistry; ISUP: International Society of Urological Pathology; MAPK
Mitogen-activated protein kinase; PR: Progesterone receptor; TMA: Tissue microarray; UICC: International Union Against Cancer.

\section{Acknowledgements}

We are grateful to Melanie Witt, Inge Brandt, Maren Eisenberg, Christina Möller-Koop, and Sünje Seekamp for excellent technical assistance.

\section{Authors' contributions}

AM, RS, MK, DH, KM, SW, TC, CH-M, AH contributed to conception, design, data collection, data analysis and manuscript writing. $A M$; TW, NG, FB, AL, CF, CB: immunohistochemistry analysis. RK, TK, AM: conception and design, collection of samples. PL, DD, SS, RU, SM, EB: data collection and data analysis. AM, GS,

WW, RS: study supervision. All authors read and approved the final manuscript.

\section{Funding}

Open Access funding enabled and organized by Projekt DEAL.

\section{Availability of data and materials}

All data generated or analyzed during this study are included in this published article.

\section{Ethics approval and consent to participate}

The usage of archived diagnostic left-over tissues for manufacturing of tissue microarrays, their analysis for research purposes and patient data analysis has been approved by local laws (HmbKHG, §12,1) and by the local ethics committee (Ethics commission Hamburg, WF-049/09). All work has been carried out in compliance with the Helsinki Declaration.

\section{Consent for publication}

Not applicable.

\section{Competing interests}

The Institute of Pathology of the UKE receives royalties on the sale of CK18 clone MSVA-118 from MS Validated Antibodies GmbH (owned by a family member of GS)

\section{Author details}

${ }^{1}$ Institute of Pathology, University Medical Center Hamburg-Eppendorf, Martinistr. 52, 20246 Hamburg, Germany. ${ }^{2}$ Institute of Pathology, Clinical Center Osnabrueck, Osnabrueck, Germany. ${ }^{3}$ Department of Pathology, Academic Hospital Fuerth, Fuerth, Germany.

Received: 21 October 2020 Accepted: 18 January 2021

Published online: 15 February 2021

\section{References}

Afrem MC, CraiToiu S, Hincu MC, Manolea HO, Nicolae V, CraiToiu MM. Study of CK18 and GDF5 immunoexpression in oral squamous cell carcinoma and their prognostic value. Rom J Morphol Embryol. 2016;57(1):167-72.

Agaimy A, Kirsche H, Semrau S, Iro H, Hartmann A. Cytokeratin-positive epithelioid angiosarcoma presenting in the tonsil: a diagnostic challenge. Hum Pathol. 2012;43(7):1142-7.

Akiba J, Nakashima O, Hattori S, Naito Y, Kusano H, Kondo R, et al. The expression of arginase-1, keratin (K) 8 and K18 in combined hepatocellularcholangiocarcinoma, subtypes with stem-cell features, intermediate-cell type. J Clin Pathol. 2016;69(10):846-51.

Balm AJ, Hageman PC, van Doornewaard MH, Groeneveld EM, Ivanyi D. Cytokeratin 18 expression in squamous cell carcinoma of the head and neck. Eur Arch Otorhinolaryngol. 1996;253(4-5):227-33.

Bartek J, Vojtesek B, Staskova Z, Bartkova J, Kerekes Z, Rejthar A, et al. A series of 14 new monoclonal antibodies to keratins: characterization and value in diagnostic histopathology. J Pathol. 1991;164(3):215-24.

Biermann K, Heukamp LC, Steger K, Zhou H, Franke FE, Sonnack V, et al. Genome-wide expression profiling reveals new insights into pathogenesis and progression of testicular germ cell tumors. Cancer Genomics Proteomics. 2007;4(5):359-67. 
Broers JL, Ramaekers FC, Rot MK, Oostendorp T, Huysmans A, van Muijen GN, et al. Cytokeratins in different types of human lung cancer as monitored by chain-specific monoclonal antibodies. Cancer Res. 1988;48(11):3221-9.

Cajaiba MM, Neves JI, Casarotti FF, de Camargo B, ChapChap P, Sredni ST, et al. Hepatoblastomas and liver development: a study of cytokeratin immunoexpression in twenty-nine hepatoblastomas. Pediatr Dev Pathol. 2006;9(3):196-202.

Caulin C, Ware CF, Magin TM, Oshima RG. Keratin-dependent, epithelial resistance to tumor necrosis factor-induced apoptosis. J Cell Biol. 2000;149(1):17-22.

Chen Y, Cui T, Yang L, Mireskandari M, Knoesel T, Zhang Q, et al. The diagnostic value of cytokeratin 5/6,14, 17, and 18 expression in human non-small cell lung cancer. Oncology. 2011;80(5-6):333-40.

Chu PG, Weiss LM. Keratin expression in human tissues and neoplasms. Histopathology. 2002;40(5):403-39.

Coulombe PA, Wong P. Cytoplasmic intermediate filaments revealed as dynamic and multipurpose scaffolds. Nat Cell Biol. 2004;6(8):699-706.

Dancau AM, Simon R, Mirlacher M, Sauter G. Tissue microarrays. Methods Mol Biol. 2016;1381:53-65.

Emerson RE, Ulbright TM. The use of immunohistochemistry in the differential diagnosis of tumors of the testis and paratestis. Semin Diagn Pathol. 2005;22(1):33-50.

Faridi N, Bathaie SZ, Abroun S, Farzaneh P, Karbasian H, Tamanoi F, et al. Isolation and characterization of the primary epithelial breast cancer cells and the adjacent normal epithelial cells from Iranian women's breast cancer tumors. Cytotechnology. 2018;70(2):625-39.

Fillies T, Werkmeister R, Packeisen J, Brandt B, Morin P, Weingart D, et al. Cytokeratin $8 / 18$ expression indicates a poor prognosis in squamous cell carcinomas of the oral cavity. BMC Cancer. 2006;6:10.

Fraune C, Simon R, Hube-Magg C, Makrypidi-Fraune G, Kahler C, Kluth M, et al. MMR deficiency in urothelial carcinoma of the bladder presents with temporal and spatial homogeneity throughout the tumor mass. Urol Oncol. 2020;38(5):488-95.

Fuchs E, Weber K. Intermediate filaments: structure, dynamics, function, and disease. Annu Rev Biochem. 1994;63:345-82.

Galarneau L, Loranger A, Gilbert S, Marceau N. Keratins modulate hepatic cell adhesion, size and G1/S transition. Exp Cell Res. 2007;313(1):179-94.

Gilbert S, Loranger A, Daigle N, Marceau N. Simple epithelium keratins 8 and 18 provide resistance to Fas-mediated apoptosis. The protection occurs through a receptor-targeting modulation. J Cell Biol. 2001;154(4):763-73.

Gilbert S, Loranger A, Marceau N. Keratins modulate c-Flip/extracellular signalregulated kinase 1 and 2 antiapoptotic signaling in simple epithelial cells. Mol Cell Biol. 2004;24(16):7072-81.

Hsu JD, Yao CC, Lee MY, Kok LF, Wang PH, Tyan YS, et al. True cytokeratin 8/18 immunohistochemistry is of no use in distinguishing between primary endocervical and endometrial adenocarcinomas in a tissue microarray study. Int J Gynecol Pathol. 2010;29(3):282-9.

Ishida H, Kasajima A, Kamei T, Miura T, Oka N, Yazdani S, et al. SOX2 and Rb1 in esophageal small-cell carcinoma: their possible involvement in pathogenesis. Mod Pathol. 2017;30(5):660-71.

Knosel T, Emde V, Schluns K, Schlag PM, Dietel M, Petersen I. Cytokeratin profiles identify diagnostic signatures in colorectal cancer using multiplex analysis of tissue microarrays. Cell Oncol. 2006;28(4):167-75.

Knowles MA, Hurst CD. Molecular biology of bladder cancer: new insights into pathogenesis and clinical diversity. Nat Rev Cancer. 2015;15(1):25-41.

Kononen J, Bubendorf L, Kallioniemi A, Barlund M, Schraml P, Leighton S, et al. Tissue microarrays for high-throughput molecular profiling of tumor specimens. Nat Med. 1998;4(7):844-7.

Lam KY, Lui MC, Lo CY. Cytokeratin expression profiles in thyroid carcinomas. Eur J Surg Oncol. 2001;27(7):631-5.

Levy R, Czernobilsky B, Geiger B. Cytokeratin polypeptide in gastrointestinal adenocarcinomas displaying squamous differentiation. Hum Pathol. 1992;23(6):695-702.

Lyda MH, Weiss LM. Immunoreactivity for epithelial and neuroendocrine antibodies are useful in the differential diagnosis of lung carcinomas. Hum Pathol. 2000;31(8):980-7.

Makino T, Yamasaki M, Takeno A, Shirakawa M, Miyata H, Takiguchi S, et al. Cytokeratins 18 and 8 are poor prognostic markers in patients with squamous cell carcinoma of the oesophagus. Br J Cancer. 2009;101(8):1298-306.
Malzahn K, Mitze M, Thoenes M, Moll R. Biological and prognostic significance of stratified epithelial cytokeratins in infiltrating ductal breast carcinomas. Virchows Arch. 1998;433(2):119-29.

Miettinen M, Fetsch JF. Distribution of keratins in normal endothelial cells and a spectrum of vascular tumors: implications in tumor diagnosis. Hum Pathol. 2000;31(9):1062-7.

Moll R, Franke WW, Schiller DL, Geiger B, Krepler R. The catalog of human cytokeratins: patterns of expression in normal epithelia, tumors and cultured cells. Cell. 1982;31(1):11-24.

Moll R, Zimbelmann R, Goldschmidt MD, Keith M, Laufer J, Kasper M, et al. The human gene encoding cytokeratin 20 and its expression during fetal development and in gastrointestinal carcinomas. Differentiation. 1993:53(2):75-93.

Nanda KD, Ranganathan K, Devi U, Joshua E. Increased expression of CK8 and CK18 in leukoplakia, oral submucous fibrosis, and oral squamous cell carcinoma: an immunohistochemistry study. Oral Surg Oral Med Oral Pathol Oral Radiol. 2012;113(2):245-53.

Nhung NV, Mirejovsky P, Mirejovsky T, Melinova L. Cytokeratins and lung carcinomas. Cesk Patol. 1999;35(3):80-4.

Notohara K, Hamazaki S, Tsukayama C, Nakamoto S, Kawabata K, Mizobuchi K, et al. Solid-pseudopapillary tumor of the pancreas: immunohistochemical localization of neuroendocrine markers and CD10. Am J Surg Pathol. 2000;24(10):1361-71.

Oshima RG, Baribault H, Caulin C. Oncogenic regulation and function of keratins 8 and 18. Cancer Metastasis Rev. 1996;15(4):445-71.

Poniecka AW, Alexis JB. An immunohistochemical study of basal cell carcinoma and trichoepithelioma. Am J Dermatopathol. 1999;21 (4):332-6.

Raju GC. Expression of the cytokeratin marker CAM 5.2 in cervical neoplasia. Histopathology. 1988;12(4):437-43.

Rotty JD, Hart GW, Coulombe PA. Stressing the role of O-GICNAc: linking cell survival to keratin modification. Nat Cell Biol. 2010;12(9):847-9.

Safadi RA, Abdullah NI, Alaaraj RF, Bader DH, Divakar DD, Hamasha AA, et al. Clinical and histopathologic prognostic implications of the expression of cytokeratins $8,10,13,14,16,18$ and 19 in oral and oropharyngeal squamous cell carcinoma. Arch Oral Biol. 2019:99:1-8.

Saper CB. A guide to the perplexed on the specificity of antibodies. J Histochem Cytochem. 2009;57(1):1-5.

Shao MM, Chan SK, Yu AM, Lam CC, Tsang JY, Lui PC, et al. Keratin expression in breast cancers. Virchows Arch. 2012;461(3):313-22.

Shimonishi T, Miyazaki K, Nakanuma Y. Cytokeratin profile relates to histological subtypes and intrahepatic location of intrahepatic cholangiocarcinoma and primary sites of metastatic adenocarcinoma of liver. Histopathology. 2000;37(1):55-63.

Sinard JH. Immunohistochemical distinction of ocular sebaceous carcinoma from basal cell and squamous cell carcinoma. Arch Ophthalmol. 1999:117(6):776-83.

Skinnider BF, Folpe AL, Hennigar RA, Lim SD, Cohen C, Tamboli P, et al. Distribution of cytokeratins and vimentin in adult renal neoplasms and normal renal tissue: potential utility of a cytokeratin antibody panel in the differential diagnosis of renal tumors. Am J Surg Pathol. 2005;29(6):747-54.

Tapia C, Schraml P, Simon R, Al-Kuraya KS, Maurer R, Mirlacher M, et al. HER2 analysis in breast cancer: reduced immunoreactivity in FISH non-informative cancer biopsies. Int J Oncol. 2004;25(6):1551-7.

Ueda G, Sawada M, Ogawa H, Tanizawa O, Tsujimoto M. Immunohistochemical study of cytokeratin 7 for the differential diagnosis of adenocarcinomas in the ovary. Gynecol Oncol. 1993;51(2):219-23.

Walker LC, Harris GC, Holloway AJ, McKenzie GW, Wells JE, Robinson BA, et al. Cytokeratin KRT8/18 expression differentiates distinct subtypes of grade 3 invasive ductal carcinoma of the breast. Cancer Genet Cytogenet. 2007;178(2):94-103.

Waseem A, Alexander CM, Steel JB, Lane EB. Embryonic simple epithelial keratins 8 and 18: chromosomal location emphasizes difference from other keratin pairs. New Biol. 1990;2(5):464-78.

Weng YR, Cui Y, Fang JY. Biological functions of cytokeratin 18 in cancer. Mol Cancer Res. 2012;10(4):485-93.

Willipinski-Stapelfeldt B, Riethdorf S, Assmann V, Woelfle U, Rau T, Sauter G, et al. Changes in cytoskeletal protein composition indicative of an epithelial-mesenchymal transition in human micrometastatic and primary breast carcinoma cells. Clin Cancer Res. 2005;11(22):8006-14. 
Woelfle U, Sauter G, Santjer S, Brakenhoff R, Pantel K. Down-regulated expression of cytokeratin 18 promotes progression of human breast cancer. Clin Cancer Res. 2004;10(8):2670-4.

Yang ZY, Zhang HY, Wang F, Ma YH, Li YY, He HL, et al. Expression of cytokeratin(CK)7, CK8/18, CK19 and p40 in esophageal squamous cell carcinoma and their correlation with prognosis. Zhonghua Bing Li Xue Za Zhi. 2018:47(11):834-9.

Yee DS, Tang Y, Li X, Liu Z, Guo Y, Ghaffar S, et al. The Wnt inhibitory factor 1 restoration in prostate cancer cells was associated with reduced tumor growth, decreased capacity of cell migration and invasion and a reversal of epithelial to mesenchymal transition. Mol Cancer. 2010;9:162.

Yoshikawa K, Katagata Y, Kondo S. Biochemical and immunohistochemical analyses of keratin expression in basal cell carcinoma. J Dermatol Sci. 1998;17(1):15-23.

Young GD, Winokur TS, Cerfolio RJ, Van Tine BA, Chow LT, Okoh V, et al. Differential expression and biodistribution of cytokeratin 18 and desmoplakins in non-small cell lung carcinoma subtypes. Lung Cancer. 2002;36(2):133-41.

Zhang XS, Zhang ZH, Jin X, Wei P, Hu XQ, Chen M, et al. Dedifferentiation of adult monkey Sertoli cells through activation of extracellularly regulated kinase 1/2 induced by heat treatment. Endocrinology. 2006;147(3):1237-45.

Zhang B, Wang J, Liu W, Yin Y, Qian D, Zhang H, et al. Cytokeratin 18 knockdown decreases cell migration and increases chemosensitivity in nonsmall cell lung cancer. J Cancer Res Clin Oncol. 2016;142(12):2479-87.

\section{Publisher's Note}

Springer Nature remains neutral with regard to jurisdictional claims in published maps and institutional affiliations.
Ready to submit your research? Choose BMC and benefit from:

- fast, convenient online submission

- thorough peer review by experienced researchers in your field

- rapid publication on acceptance

- support for research data, including large and complex data types

- gold Open Access which fosters wider collaboration and increased citations

- maximum visibility for your research: over $100 \mathrm{M}$ website views per year

At BMC, research is always in progress.

Learn more biomedcentral.com/submissions 